\title{
The Silence of the Subaltern in the Partition of India: Bengali Gendered Trauma NARRATIVES IN SHOBHa RAO'S “ThE LOST RibBON” AND RAMAPADA CHAUDHURI'S "EMBRACE"
}

\author{
DOLORS ORTEGA ARÉVALO \\ Universitat de Barcelona \\ dolors.ortega@ub.edu
}

Received: 19-12-2020

Accepted: 20-01-2021

\begin{abstract}
(ब) (1)
ABSTRACT

The Partition of India was one of the crucial moments marking the transition between the colonial and postcolonial era. Partition has become ever since a long-term process that continues to elicit political, cultural and emotional contexts in South Asia. The creation of Pakistan as a homeland for South Asian Muslims involved the division of Bengal and Punjab along religious lines and while the celebratory narratives of decolonization and nationhood marked the official historiographies of 1947, trauma, loss and displacement were not part of the narrative. The following article focuses on the experience of abducted women in Bengal in the communal riots during the Partition of India. This analysis stems from a brief overview of the silence that has permeated the partition of Bengal within historiography and the scarce literary response that has articulated those silences. It moves on to the analysis of the violence that abducted women suffered in this context. Finally, it deals with two short stories, "The Lost Ribbon" and "Embrace," which situate gender trauma narratives by showing two radically different responses to the event of becoming a mother of an abductor's child on the other side of the border and the effect that displacement and forced repatriation has upon female bodies.
\end{abstract}

KEYWORDS: partition of India; Bengal; gender; trauma; abduction; displacement; repatriation.

RESUMEN El silencio del subalterno en la partición de la India: relatos de trauma y género en "The Lost Ribbon" (Shobha Rao) y "Embrace" (Ramapada Chaudhuri)

La partición de la India constituye unos de los momentos cruciales que han marcado la transición entre la era colonial y poscolonial. Desde entonces, la partición se ha erigido como un proceso a largo plazo que sigue propiciando contextos políticos, culturales y emocionales en Asia del Sur. La creación de Pakistán como patria para los musulmanes asiáticos del Sur tuvo como resultado la división de Bengala y Punjab según divisiones religiosas. Mientras que la historiografía oficial de 1947 estaba marcada por relatos triunfalistas de decolonización y nacionalismo, elementos como el trauma, la pérdida o el desplazamiento quedaron fuera del relato. El siguiente artículo se centra en la experiencia de las mujeres secuestradas en Bengal, en los disturbios entre comunidades durante la partición de la India. Este análisis parte de una breve aproximación al silencio que ha presidido la historiografia de la partición de Bengala y la escasa respuesta literaria que ha articulado estos silencios. El artículo trata la violencia que las mujeres secuestradas sufrieron en este contexto y finalmente se centra en los dos relatos breves, "The Lost Ribbon" y "Embrace", que sitúan el relato del trauma y el género mediante dos respuestas radicalmente diferentes al hecho de ser madre de un hijo de secuestrador más allá de la frontera. Así mismo analiza el efecto que el desplazamiento y la repatriación forzosa tiene sobre los cuerpos femeninos.

Palabras ClaVe: La partición de la India; Bengala; relatos de trauma y género; mujeres secuestradas; desplazamiento; repatriación forzada 
She stands mute, her hands listless at her side

Her glance dead, her looks far away

Remembering each slaughtered head

Each torn breast, each splintered babe. (...)

She is the booty the son has brought home

The last bargain thrown in the colossal loot.

“An Abducted Woman: The Loot" (Fraser, 2008: 295)

The experience of trauma is an overwhelming and self-shattering event that is frequently theorised as unspeakable and resistant to representation (Whitlock and Douglas, 2009: 1). When a whole community endures the traumatic experience, trauma lives in both the collective and the individual body. It is then when the act of disentangling the threads of the unspoken becomes a complex network of resistance, remembering, forgetting and silence.

If we understand the relationship between remembering and forgetting as something relational, it comes as no surprise that the space between the two is occupied by silence. Silence is meaningful. It is necessary. It is a force in itself to stimulate remembrance. In addition, neuroscientists, psychologists and even philosophers have argued that remembrance is nothing but a reinterpretation of the past, in the present moment. By remembering, we re-member, re-map, rewrite our experience. This is how memory is always narrativised or textualised, turned into a text to be read, which does not rely on stable meanings. What we remember and what we forget changes with time. Memories are contingent on the moment and circumstances of remembering, which might determine who is authorised to remember and what is to be remembered, both at a personal and a collective level. For those subaltern subjects that have been forgotten or silenced at a collective level and left aside from the mainstream collective narrative, trauma narrative seems a major opportunity to signify their experience and to heal their wounds.

According to Jeffrey C. Alexander collective trauma is the result of a sociocultural narrative act of constructing traumatic experiences. Literature, then, performs a major part in what Alexander calls the "trauma process": the process that gives narrative shape and meaning to "harmful or overwhelming phenomena, which are believed to have deeply harmed collective identity" (2004: 10). Nowadays, trauma is not only understood as acute, individual, and eventbased, but also as collective and chronic; trauma can weaken individuals and communities, but it can also lead to a stronger sense of identity and a renewed social cohesion. As Laura Brown has proposed in her essay, "Not Outside the Range: Feminist Perspective on Psychic Trauma," anxiety, melancholia, withdrawal and other symptoms of Post-Traumatic Stress Disorder are not 
only long-term - belonging as they do to an extended temporality - but they can also spread intergenerationally through narrative and social transmissions and witnessing (1995: 108).

Consequently, trauma narrative can contribute to articulate the language of trauma and the silence of its mute repetition. According to Caruth. "trauma is not experienced as a mere repression or defence, but as a temporal delay that carries the individual beyond the shock of the first moment. The trauma is a repeated suffering of the event, but it is also a continual leaving of its site" (1995: 10). In this continual leaving of its wounding site, trauma narrative can foster cross-cultural and interpersonal solidarity and the creation of new forms of community as Caruth adds, “...trauma itself may provide the very link between cultures: not as a simple understanding of the pasts of others but rather, within the traumas of contemporary history, as our ability to listen through the departures we have all taken from ourselves." (1995: 11) Postcolonial literature provides many examples that support the claim that trauma itself instigates a strong need for narrative in order to come to terms with the aftermath of colonial wounding. The textualisation of mourning is empowering to individuals and their communities, and it is in fact crucial to cultural survival. ${ }^{1}$

The aim of the following article is to analyse, from the lens of trauma narrative in a context of gender-based violence, the experience of silenced bodies that have been doubly excluded from collective narratives; in particular, the experience of abducted women in Bengal in the communal riots during the Partition of India. In order to do so, this article will move from a very brief overview of the silence that has permeated the partition of Bengal within historiography and the literary response that has articulated those silences, to move on to the analysis of the violence that abducted women suffered in this context. This article analyses two short stories, which are to be considered fictionalised accounts of life writing episodes - "The Lost Ribbon" and "Embrace" — written by Shobha Rao, a second generation writer from the South, and Ramapada Chaudhuri, a Bengali novelist and short story writer. These two stories situate gender trauma narratives by showing two radically different responses to the event of becoming a mother of an abductor's child on the other side of the border. They both revolve around the Bengali female experience of repatriation, displacement, loss and motherhood.

\footnotetext{
${ }^{1}$ While for Caruth trauma narrative must be regarded as leading to increased indeterminacy, denying the possibility of resolution and recovery, for Herman (1997) trauma narrative is therapeutic, enabling psychic integration and eventual resolution of trauma.

2 The former story is included in a book written by the same author, An Unrestored Woman (2016) and the latter is included in the Bashabi Fraser edited collection Bengal Partition stories. An Unclosed Chapter (2008).
} 


\section{The other side of Partition: The silence of the East}

The creation of Pakistan as a homeland for South Asian Muslims involved the division of Bengal and the Punjab along religious lines and, while the celebratory narratives of decolonization and nationhood marked the official historiographies of 1947, trauma, loss and displacement were left out of the question. As Tomsky points out, “the mourning of partition's victims and the working through of its manifold violences and losses have yet to be achieved" (2009: 60). Instead of acknowledging the trauma, these new nations focused on the triumph of Independence over the colonial past. It was not until the 1980 s that Partition received discursive space in official historiography or memory. In the 1990s and the first decade of the 21 st century, revisionist historiographical, sociological and cultural scholarship on Partition was developed. Although the focus was first on testimonial narratives, oral histories, and empirical studies, more recent historiography of Partition has tended to open its archival scope and rely on literary texts as artifacts that catalyse untold memories.

According to revisionist historians such as Urvashi Butalia in The Other Side of Silence, Partition displaced about twelve million people; killed at least a million; countless homes were abandoned or destroyed; properties, families, and cultures were divided as new national borders were drawn over older ethnic, linguistic and cultural identities. It involved large-scale violence, mass female abduction and mutilation, malnutrition, contagious diseases, and refugee camps.

It was often noted that although the eastern and western borderlands of India went through a similar fate in 1947 and similar pains of violence, abduction, migration and resettlement, there were also certain important differences in the process and outcome between the two experiences. While the literature of the Punjab Partition openly depicts the trauma and horrors of the 1947 massacres, the relatively less known literary works on the Bengal Partition throw a rare and useful light on the continuing political, social and economic uncertainties of the time and the tortuous journey of resettlement such uncertainties led to.

In northern and western India, the human drama of Partition has been consistently taken up as the theme of hundreds of novels, stories and poems, resulting in the emergence of a rich genre of 'Partition literature'. However, on the eastern side, a deep silence has stood out in the field of literature, thus rendering 'Partition literature' a rather lopsided character. Maybe this is so because in Bengal, unlike in the Punjab, migration has not been a matter of a short stretch of time. Two generations after Partition, migration across borders continued, partly, due to the 1971 
Bangladeshi War of Independence. Passports were introduced from 1953 onwards and visas were required only after the 1965 Indo-Pakistan war. (Baghi and Dasgupta, 2007)

There has been a tendency on the Western borders of India to focus on the communal and violent nature of Partition and the mass exodus that went with it due to forced migration. Although Bengal borders enjoyed open borders for a long period of time, this is not to say that the Bengali homeland was not abruptly cut into two random parts with millions of people uprooted, tortured and butchered. But strangely, within Bengali culture, especially the field of literature, a steady silence has permeated the devastating realities. In addition, this discrete literary response seems to have followed different paths within divided Bengal. As Meghna Guha Thakurta points out: "although fiction and autobiographical writings have dominated the Partition discourse on both sides [in Bengal], the voices of Hindu migrants from East Bengal have been more prominent than Muslim migrants from West Bengal.” (2007: 101)

Bashabi Fraser (2008) claims that much has been written on the history, politics and social background which led to Bengal's Partition, but the actual experience of the people who were affected by the Partition has not been explored and can be recovered from oral histories and interviews or traced from fiction, retelling the violence, the trauma that dislocated or displaced people's experiences. Literature has emerged as an alternative archive of the times and a very fruitful account of life writing experiences.

Although Bengali literature of the post-1947 years seems to be dominated by silence, more contemporary Bengali authors seem less reluctant to fill in the generational gap. This generalised discomfort of authors to deal with violence and humiliation in fictional narratives is compensated, to a certain extent, by writers of autobiography, whose narratives sometimes entail vivid descriptions of riots witnessed first-hand. Although most of these memoirs or life narratives are still not translated into English, some exceptions are to be found in Ahmed Imtiaz's Memories of a Genocidal Partition: The Haunting Tale of Victims, Witnesses, and Perpetrators (2002), and Sunanda Sikdar's Life Long Ago (2014).

As for Partition fictional narratives in Bengal, here again, the responses in English are scarce and the short story emerges as the most fruitful genre ${ }^{3}$. These short story anthologies, more than a single text, embrace a polyphony of voices, a wide range of Partition experiences that provide the reader with a sense of collectivity; collective experiences capable of articulating a

\footnotetext{
${ }^{3}$ See Debjani Sengupta's Mapmaking: Partition Stories From 2 Bengals (2003), Bashabi Fraser's Bengal Partition Stories: An unclosed chapter (2008) and Alok Bhalla's Stories About the Partition of India (2012), which has been re-edited to add a fourth volume which includes a large number of stories from Bengal.
} 
trauma that is lived in the collective body.

With the exception of Sunil Gangopadhyay's East-West and Arjun, and Jyotirmoyee Devi's The River Churning: A Partition Novel, the most prominent examples come from 2nd/3rd generation writers, with examples such as Tahmina Anan's A Golden Age and Amitav Ghosh's The Shadow Lines. Many of the responses to Partition have come from the diaspora, particularly the more contemporary ones, from people who did not live through the period and in some cases who have spent little of their lives in South Asia, as Harrington points out.

What becomes apparent is the natural and understandable relationship between the silent and silenced Bengal Partition and what has been called the marginal space of the diaspora. The responses from this space occupy neither the space of the born and bred South Asian, writing in the vernacular, nor that of the complete foreigner with an outside view of the event; the diaspora find themselves in an- Other space. (2016: 2)

Second-generation post-Partition authors write from a generational, temporal and spatial distance, and have the opportunity to put into discourse what has not been signified before, from an-Other subject position, neither from the inside nor from the outside of Partition. There is a fundamental element of transgenerational traumatic legacy involved in this Other-space, where subjects that have not gone through a traumatic experience inherit it by being exposed to residual narratives or narratives of silence.

Shobha Rao, a member of the Indian-American diaspora stands out as a good example of the above-mentioned. In An Unrestored Woman, Rao tackles the theme of Partition from that Other place, by turning away from the Eastern-Western divide and the religious-based approach, and by placing the most vulnerable bodies of both sides of the partition (often invisibilised by Partition historiography) at the center of the narrative in a context of gender violence and aggression against women. Rao's collection does not respond to a religious or geographical logic. It includes stories from the Eastern side and the Western side of the Partition. Rao's literary response aims to articulate the trauma of those women whose experiences have been silenced by the master narrative of history, the subaltern wounds that have been systematically excluded from official historical records of Partition and the very same unofficial histories that have been passed on from generation to generation.

Rao focuses on the narrative of trauma from a gender perspective to demonstrate that gender hierarchies intensify in a context of violence. In an interview in 2016, Rao explains that she chose the interlinked-paired format of her stories in order to show the extent to which trauma experiences are long-term processes that become collective narratives:

I wanted to explore the path of trauma. I was reading an article about how not only the 
wiring in the brains of the survivors of the Holocaust had been altered by the trauma, but also the wiring in the brains of their children and their grandchildren. After reading that article, I became interested in how trauma travels across space and time. How does it alter those around us, those we don't even realize we are altering? So the linked stories seemed a good way to follow sorrow, trauma, tragedy, and watch it over generations, or sometimes only days or hours. (Hong)

As a second-generation writer, originally from the South of India, Rao is a good example of the transmission and circulation of collective traumas from one generation to another.

No one in my family was involved in Partition. I am from South India, and most of the events of Partition occurred in North India, so my family was not affected - and by this, I mean, violently - by the events. But Partition was a global event, and it is seared into the consciousness of all Indians and Pakistanis. To this day — very much to this day. (Hong)

Despite not having been directly involved in Partition, not having been "affected violently by the events," this collective trauma narrative "seared into the consciousness of all Indians." Rao carried out a meticulous research. She gathered information from testimonies, interviews, memoirs and autobiographies, and fictionalised the lives of those women who remained on the margins of history. Rao's stories serve as a catalyst to account for the real life experiences of those subjects that have been silenced and ignored.

\section{Doubly-silenced bodies: The Untold Stories of Bengali Abducted Women during Partition}

Almost a million people — Hindus, Muslims, Sikhs — would lose their lives in the violence of history's largest mass migration. "As with the majority of conflicts, [Rao writes in her introductory 'Author's Note'], women and children during the Partition of India and Pakistan were often the most vulnerable." (2017: xii) It is estimated that some 50,000 Muslim women in India and 33,000 Hindu and Sikh women in Pakistan were abducted, Rao explains. In order to stop massive abduction, the Indian and Pakistani governments reached an agreement, the InterDominion Treaty of December 6, 1947, to recover as many abducted women as could be found. The operation came to be known as the Central Recovery Operation (Butalia,114). Finally, the Abducted Persons (Recovery and Restoration) Act of 1949 legislated the return of these abducted women, making them officially "recovered," if not, in Rao's view, "restored": “... while the recovery of a person is possible, the restoration of a human being to her original state is not." (xii) This Act fostered the creation of camps where women would be detained until they could be repatriated and sent back to their former families. The Central Recovery Operation did not cease 
until 1956 and implied a second uprooting. Women would become objects of exchange that needed to be returned to their owners.

During the partition, women were territorialised, abducted, objectified, taken away by force or left behind by their own families in exchange for crossing the border. The female body became a battlefield to be conquered by either side. Female bodies were doubly marked, doubly repressed and socially marginalised. These abducted women became domestic servants, sex slaves. Many of them were sold into prostitution and very few were to be married to their abductors.

However, when being repatriated on State initiative, many abducted women protested. They refused to go back to their former homes but they were not given a choice. Others were not reluctant to leave. Whatever the case, they were forced to do so to face just another traumatic experience. They would have to face their families' rejection. Paradoxically, "their families, who had earlier filed reports and urged the government to recover their women, were now no longer willing to take them back." (Butalia, 2000: 126)

That was, according to Debali Mookerjea-Leonard, the final stage of a long process that had mystified the female body within national codes. Furthermore, discursive constructions of Hindu femininity had traditionally been trapped in patriarchal discursive practices that legitimised different forms of violence perpetrated against the female body.

The Partition riots of 1946-47 and the destabilization of community alliances that they entailed treated women's bodies as sites for the performance of identity. According to the same patriarchal logic that resulted in the mass rape of women from the other religious community (Muslim), the purity of Hindu and Sikh women became a political prerequisite for their belonging to the new nation. (In the communal violence surrounding Partition, Hindu and Sikh women sometimes committed suicide or were murdered by kinsmen, and these acts designed to thwart the enemy's aims to dishonour the nation by violating its women were lauded as self-sacrifice). (Mookerjea-Leonard, 2015: 13)

While the female body was instrumentalised and reified into an object of shame for the community she belonged to by patriarchal cruelties from the other side, the female body from one's own community was sacralised, fetishized and venerated as the paragon of the honour of the nation. The chaste female body became the vessel of an essential Indian/Hindu identity and feminine sexual purity became the transcendental signifier for national identity. Jasodhara Bagchi points out that "[i]n Bengal though women were not exchanged in lieu of property and chattel, the chastity belt of women's heroism to save the family honour was a signifier of the most important defence against total social disaster." (Bagchi, 2007: 19) An underlying patriarchal conspiracy coming from both sides inflicted different forms of violence upon the 
female body, leaving the abducted female bodies in an unrestored space and turning them into abject bodies for their communities.

The process of repatriation objectified abducted women as unrestored bodies that would receive the official public protection of the State and private rejection of the whole community. These unrestored bodies would suffer the violence of the other side of the border under the circumstances of abduction; the violence of the State by imposing repatriation, often uprooting women's settled lives and denying them any agency to decide by themselves what to do with their futures; and ultimately, the violence of a community that rejected them by marking their lives as permanently paralysed. Yet, the most devastating violence that women suffered during the Partition was family violence:

The abduction and rape of women, the physical mutilation of their bodies, the tattooing of their sexual orders with symbols of the other religion -these acts had been universally condemned. But no mention was made of family violence by anyone---neither the families, nor the State, nor indeed by historians. (Butalia, 2000: 162)

Abducted women were rejected by their own families, and sometimes killed. Feminicides and mass suicide happened within family contexts. The female members of the family were killed and "martyred" by the men of their own families in order to "save" the purity of their religion.

As Butalia states, for Hindus, purity could be more easily accepted if the woman was alone rather than when she had children born of a mixed union, which would stand as a constant reminder of the impurity of a woman that had had sex with a man of the other religion. In that case, women were given two options: either to keep their children with them and stay (most probably stagnated in an ashram for the rest of their lives) or to give their children up to be kept in orphanages and go back to their families. The case would be even more complex for pregnant women, who also had two options. They would be sent to appointed places to have their children who were often given in adoption, or they would have an abortion financed by the State at a time when abortion was illegal.

...the greatest hurdle in the way of forcible recovery was the women's reluctance to leave their children... Special homes were then set up where unwilling persons could be housed and given time to make up their minds 'without fear or pressure.' How much of a free choice this actually gave women is another question. (Butalia, 2000: 130)

Although forcible recovery met women's resistance to abandon their children on the other side of the border, the State found the way to apply coercive measures to push them back to their former homes, dispossessed, unsettled and completely torn. According to Rachel Weber "as nations and communities reconstruct themselves, there is bound to be a change in the way women are perceived, signified and deployed to serve new purposes and agendas." (2007: 70) 
Violence against women is among the world's most systematic and ubiquitous human rights violations. ${ }^{4}$ It is structural as it is ingrained in the social, religious and moral fabric of society; that is to say, in the ideological apparatuses of patriarchy. In fact, violence against women should be read as a product of unequal power relations between men and women, manifested in asymmetries in the gender division of social and cultural practices.

At the time of Partition, women's raped and mutilated bodies became recipients of patriarchal abuse and male self-referential signifiers. Women were used as a weapon to attack the other ethnic or religious community. As Jisha Menon suggests "the female body served as the terrain through which to exchange dramatic acts of violence. The gendered violence of the Partition thus positioned women between symbolic abstraction and embodiment.” (2013: 121) Women became a means to attack the enemy. They were not even the targets. Every violence inflicted on a woman's body was an attack on the other religious group's patriarchal codes. By attacking female bodies, they were problematising the other's patriarchal structures that were proved to be incapable of protecting their own vulnerable bodies: their mothers, wives and daughters.

We might find some explanations for gender-based violence when we understand it as something structural. Structural elements of gender-based violence include both the extent to which societies are characterized by social norms and practices that promote violence against women as well as the extent to which there are institutional provisions that can help to reinforce these systemic tendencies. As Young (1990: 62) points out, it is not simply the fact of violence against women that makes it a matter of social injustice rather than an individual wrong, but the fact that society at large makes these acts possible and even acceptable. Violence is ultimately a multifaceted phenomenon grounded in the interplay between factors that operate at the level of individuals, interpersonal relations, institutional contexts and the wider society.

\section{Gendered violence, abduction and repatriation in "The Lost Ribbon"}

The women in the twelve stories of An Unrestored Woman have been scapegoated by Partition, they might have started coming to terms with their traumatic memories, but they have not been restored. When being asked about the reasons why she chose to write about the Partition in $A n$

\footnotetext{
${ }^{4}$ UN Women "Defining Violence against Women and Girls" http://www.endvawnow.org/en/articles/295- definingviolence-against-women-and-girls.html (accessed 2017-05-09).
} 
Unrestored Woman, Rao explains:

I chose Partition because I wanted to find a moment in time, history, human conflict in which to explore the many themes that I was already exploring in my work. These include exile, violence, especially against women and children, migration, displacement, and the fragility of life. And so Partition emerged as that moment for me ... not only because of the toll it took on the life of the two nations involved, but also because of the individual costs, on the human scale, that it extracted.

I focused my research on studying the political and geographic history, but then I put all that research away and listened to oral histories, read countless accounts of the lives of women (not just in Partition, but in other conflicts as well), and then actually sought out people who had survived the conflict and spoke to them. It was after that that I began to write. (Hong: 2016)

Shobha Rao focuses on the violence, cruelties and brutalities inflicted upon female bodies during the time of Partition. The focus is on the vulnerability of the female body during and after this historical event. The main characters in An Unrestored Woman struggle to understand and face the violence their relation with the country, community, religion and family has triggered in them as vulnerable bodies.

In "The Lost Ribbon", a middle-aged Hindu woman remembers her traumatic past when she was kidnapped at the age of fourteen, locked in a hut, where she was raped, tortured, and became pregnant. Having to decide whether to kill her baby so as to keep her away from the abductor's cruelty -and ultimately the cruelty of the State- or to let her live without her protection, she is forced to move back to India without the baby to meet a future that does not look too promising for her:

"The child," the woman said. "She can't come."

"Where?"

"Back to India of course." Her voice was slow and measured, and yet I struggled to understand.

"But why? She is my daughter."

"But she's is a citizen of Pakistan. She's a Muslim.”(117)

(...)

You have no choice," she said.

"There are governmental treaties we must follow."

"What treaties? What governments?"

"Between India and Pakistan"

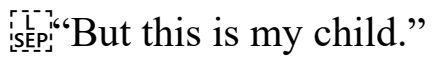

"She is a child of Pakistan," the old soldier said solemnly.

"And you, my dear, are not." (118).

The main character of the story has to face the fact that back at the time when this incident takes place, she is forced to return to India without her daughter. It was not until 1949 that the Recovery Bill redefined the status of an abducted person to enable the mothers who were to be 
repatriated to keep their children with them, since a male child under the age of sixteen or a female of whatever age would, then, be considered an abducted person and, therefore, have the opportunity to be repatriated -something that was not often successfully achieved.

Over forty years later, she feels old, she lives in a government-run hostel for single women in Amritsar and tries to keep herself busy in the futile job of counting lentils while old memories of her traumatic past linger in her mind. The story starts in an intimate confessional tone:

If I were to tell Leela what I'd done, I know what she'd say. She'd say, No mother would do that. No mother could do that. But then I looked down at my arm, at the scar left by the cigarette burn, and think, What do you know? Because what $I$ know, what I won't tell her, but what I will tell you now, is that I was long dead before I ever killed you. (105)

In the opening paragraph of the story, the first person narrator admits having killed her six-week-old baby daughter and starts a confessional soliloquy, which will unfold the mechanisms that have brought her there. The killing of the baby and the metonymical use of the scar on her arm as a signifier of the violence inflicted on her body are interconnected elements of the same signifying chain; the effects of gender violence. This first paragraph provides different elements that will permeate the whole story.

Firstly, the conditional and hypothetical mood of the first statement presents one of the main predicaments posed by the narrative; the narrator's story is a story never to be told. It is a traumatic story that has been silenced and socially repressed. as sentenced by Leela: "No mother would do it". However, the narrator's past is not a repressed memory, but a recurrent element in her life. Secondly, her silence seems to be a site of resistance. Butalia noted that women victims of Partition violence had a tendency to turn silent when asked to recount their experience, as if "words would suddenly fail speech as memory encountered something too painful, often too frightening to allow it to enter speech." (2000: 16) Her silence seems to be a chosen one: "What do you know? Because what $I$ know, what I won't tell her." (104) The narrator is aware of the fact that her experience as an abducted and tortured body is not knowable: "I was dead before I ever killed you." (104) In addition, as a mother, a victim of gender violence, she is aware of the systemic violence that her baby daughter is condemned to be exposed to in the hands of her abductor father and, by extension, in a land where her body will be doubly marked: a girl, born to an abducted mother from the other side of the border. Even the woman who assisted her with the childbirth, despite her initial suspicion and reluctance to help, sympathises with the narrator and her daughter: "I had seven myself. Only three lived... One of them only lived for a day. A girl...Smart too...She knew a day of this was more than enough." (114-115) Female 
victimization in the hands of patriarchal violence fosters female solidarity. Despite coming from two confronted communities, there is a mutual understanding and a shared experience as subaltern subjects that allow the narrator and this other woman to sympathise with each other.

This is finally how we delve into the question of violence in the story. The narrator allows herself to take action: "I told myself, if you don't kill her, he will." (106) She, who has been the victim of patriarchal violence, both at an interpersonal level and as a body subordinated to the tyrannies of the State, identifies the violent act of killing her baby daughter as an inevitable act within the context of violence during:

Thousands upon thousands were dying that summer. Entire villages were being laid waste in the crossing between India and Pakistan...I tightened my grip, I willed myself to close my eyes, to keep pressing. I felt the gentle curve of your windpipe, your brave and rumpled pulse, and I told myself, if you don't kill her, he will. (106)

The structural violence that rules her living conditions and the vulnerability that she has experienced as a subaltern body drive her to choose violence as the only possible option. Despite the traumatic effect that this violent act has on her, we may read this act as an act of selfaffirmation. In conflicts, women's bodies too often become battlefields, with violence used to humiliate and oppress them. The narrator kills her baby to protect her from the patriarchal violence that has constantly devalued her as a body and has degraded her to a vulnerable subject position. She breaks the patriarchal monopoly of violence and aligns herself to a narrative, which, as a woman, she has been excluded from. In spite of the great loss, wound and trauma that will haunt her for the rest of her life, that has been a moment of agency:

I was afraid you'd recognise the act. Know what I was doing. And in some small corner of your silvery, still-beating six-week-old heart, you'd scoff at me. You'd say, What makes you think I couldn't have withstood the world? And I would've laughed and said, It's not the world we have to withstand, My Noora, it is ourselves." (106)

The narrator wants to protect her daughter from a life full of grief, suffering and torment; a life that seems unbearable for her. The triggering element that leads to this filicide is an episode of violence performed by the abductor, who pushes the lit end of a cigarette on her arm-- when he suspects that Indian soldiers have been in the hut to take her back to India. The narrator can't stand such violence anymore: "it is easier to look at death than at pain. In one the grief lingers and then passes with time. In the other, it is relentless." (121)

Memory and remembering are essential narrative devices in the story. It is through memory that she can revisit the very traumatic episodes in her life. The narrator reflects on the nature of memory: "It's funny though, the things we suffer and the things we remember about 
that suffering [...] that's how memory works, skips like a happy pebble, even if the memory is so very far from happy. Imagine if we remembered things exactly as they happened" (107). She is aware of the fabrication of our memories. She knows that we need to forget in order to survive. After recalling the first night she was abducted, she protests: "So you see? It's no good. The pebble must skip. Otherwise we'd die a thousand deaths before we got through a single day." (110) Despite the acknowledgment that memory is selective and that these unconscious choices pave the way for our traumas to be restored, the narrator remembers, she does not block or repress her painful memories. She has reconstructed that first night he raped her when she was fourteen:

Now, when I think of that night, think of him pushing up my lehenga, smothering my face with his free hand, stuffing his fingers into my mouth to muffle my screams, I think of your grandmother's paneer. It's just a flash, really, but the softness of the cheese, the taste of the woodsmoke and the twilight in which they were prepared, the thin gold filigree of the cube of paneer breaking like skin, they all rush through me in this moment as if I were that pebble, flying through the air. Then I hit the water again, and something is pushing into me. Thin and hard and knife-edged, it pushed, pushed, until I cried out. Then I think of something else, something quite ordinary, like how cold my feet are in the winter. Or maybe how I should bring in the clothesline; it looks like rain. (107)

She has rewritten her traumatic memories so that she can handle them, by adding new signs to the recollection of a devastating episode in her life. The narrator's chronicle is articulated around a central association: her grandmother's paneer. By adding a positive memory prior to the traumatic event, the narrator compensates the alienation effect of the violence and the brutality inflicted on her. The narration of the rape is interrupted by the incursion of this other childhood memory, which adds a touch of familiarity and warmth that makes the remembering of a suffering experience more endurable. This paragraph flashes backwards and forwards from those memories into the ordinary and the narrator seems to be aware of this mechanism through the trope of the happy pebble. The whole fragment is fleshed out with sensory words and metaphors. The hardness, coldness, and edginess associated with the sexual aggression are compensated by the softness, the taste, and the delicacy of the cheese. By adding these new elements to the narrative, the narrator seems to be positioning herself one step further in the process of leaving the site of trauma. She closes this episode by establishing an emotional transference with the stars: "The door was padlocked from the inside but the small window was thrown open. That was when I saw the stars. They were horrible: those stars." (108) Her appreciation of the stars speaks for her emotional state. Her first person narration allows us, as readers, to access her inner thoughts, therefore, understanding that her silence is a chosen one. 
She has not repressed her memories of that traumatic event but, on the contrary, she has elaborated a narrative for it.

Following the narration of the rape and linking it to one of the associations that she aligns this incident with, we are introduced to the ribbon in a rather stream-of-consciousness fashion. The star-watching after the abductor has fallen asleep that first night leads the narrative to her memories of the ribbon. It works as a symbolic motif at the center of the story. The ribbon is presented as a complex epitome of the narrator's happy childhood in her town outside of Calcutta. The ribbon bridges both her daughter's and her own loss of childhood. The complexity of this motif resides in the multiplicity of meanings it affords the narrator throughout her life. Originally, the reference to this long-lasting motif is the ribbon she had worn as a child. The narration recalls the incident in which the ribbon was stolen from her by another girl: "She held it up the entire time, the white ribbon streaming and bobbing in the wind like a kite, like the long tail of a shining mystical bird." (109) At the time, she comforted herself by thinking that the transcendental meaning she had given to it would stay with her: "It's the bird, it's left me with its heart. And though I've lost its tail I haven't, I have not, lost its heart." (109)

The ribbon motif will return to her before she kills her daughter: “...the tiny yellow ribbon in your fine hair bowed and alert, watchful, as if it were standing guard, and I wrapped my hand around your neck." (103) At this point, the narrator is metaphorically aware of having lost the mystical bird's tail and heart, her daughter and her own childhood innocence: ' '...on that night, at that window, looking at those horrible stars, I knew I'd lost both." (109) The narrator kills her daughter, as she sees no other way out for her. As an abducted woman, her experience of the world has taught her that the daughter of an abducted woman from the other side of the border has no better prospect than a life of suffering and aggression. The narrator is no longer a child. She has lost her innocence. Here again, the signifying potential of the ribbon connects with other networks of meaning related to the loss of innocence. In this stream-of-consciousness mode, the narrative associates the ribbon with her memory of her father's enthusiasm or naivety towards the newborn nation after Independence:

...when Pandit Nehru had traveled through on a Delhi-bound train. My father had taken me to the station, raised me onto his shoulders, and as the train had sped past he'd pointed to one of the windows, and in the midst of the roar of the gathered crowd he'd yelled, 'See him? There! There! He is our father'...Instead I watched the thin trail of smoke disappearing westward into deepest Bengal. It looked like the ribbon I'd so recently lost." (109)

The parallelism between the thin trail of smoke from the train and the lost ribbon adds a new 
meaning to this motif by linking a personal experience with a collective one. This is a good example of the potential of the ribbon as a sign in the story. While, on a personal level, the ribbon is to be associated with the narrator's loss of innocence due to a very traumatic life experience, on a collective level, it stands for the loss of innocence of a whole nation, which has lost its mystical bird through Partition.

The narrator has been twice displaced. She was first abducted during the communal riots and forced to move somewhere in Pakistan for almost two years. Originally from Bengal, she was rescued by a soldier and sent to North West India and she does not seem to ever have the opportunity to reach her homeland again, where, most surely, all her family members must have been killed. She lives like a refugee in a State institution in Amritsar where she leads a futile life full of ritualistic practices, such as the one of counting lentils:

I'd gotten into the habit -every night, even now, even if the electricity has gone out and I have to do it by candlelight - of counting lentils...my favourites are the rare pink and orange dal lentils... and their color...Like the hidden, singing insides of seashells. Like your fingertips. (111)

It takes her thirty exact minutes every day to count the nine hundred and eighty-six lentils that she will put back in the tin until the following day. She counts and re-counts the lentils meticulously as if she was remembering or recalling memories that she does not want to forget. She cannot bear to be missing a lentil, just as she cannot bear to lose any element of her past. These thirty minutes are the minutes she gives herself to think about the past and to talk to her dead daughter. This connection is clearly established through the association of the lentils and her daughter's fingertips. This is what she does with her trauma narrative. She unfolds it by reproducing an inner monologue that touches upon the most traumatic experiences in her life and backs them up in her ongoing silence. An example of her silence is the fact that, despite Leela's insistence about her past, she never tells her anything about the horrors she went through.

\section{Abduction, repatriation and abject bodies in Ramapada Chaudhuri's "Embrace"}

Sabita's story stems from this very same context of violence but finds a very different means of resolution. During the riots of 1946, Sabita's home is attacked and she is abducted. She is not going to be doubly displaced. She is recovered by the police and restored to her family, being forced to go back home a year and a half later.

Unlike Rao's narrator, Sabita is allowed to take her eight-month-old son with her when she is repatriated. Back home, she will have to deal with her family's response to the fact that 
she has had a baby with her abductor. The story starts from the narration of the traumatic event of her abduction in the communal riots:

A fire had seared through the darkness that night. And with it, the sound of helpless wailing. The noise made by those blood-suckers and the desperate cries of the innocent people had filled the air. Sabita had woken up from her sleep and it seemed as if a terrible fear had gripped her. There was also an expression of fearful amazement in her parents' eyes. Their faces seemed as white as washed sheets, as they shrieked in panic. It was only a few moments' wait. And then those demons...Those dark, shadowy men... They came closer now. Some of them were armed with fire torches, while others wielded daggers. And then something had happened which Sabina couldn't quite recollect now. Maybe she had lost consciousness. She had only watched with mute and innocent eyes. There was blood everywhere. (339)

One of the most significant elements of this description is Sabita's inability to remember what must have been the moment of her abduction. This gap in her memory might respond to her unconscious blocking of the traumatic experience. Despite the vivid and expressive description of this episode of violence, Chaudhuri's omniscient narrator creates an inevitable distance, which does not provide the reader with direct access to Sabita's mind. Readers do not follow her inner thoughts. Thus, it is difficult to elucidate the context of this gap and silence. Neither can we witness her inner wounding and grieving process as we cannot follow the psychic mechanisms which enabled her to block those memories, nor can we identify her trauma narrative in relation to the original traumatic event.

From the very beginning, the story revolves around the problematic encounter that Sabita is going to face with her family: "Maybe they had even forgotten the dark stain of dishonour that had fallen on the otherwise untainted reputation of their family lineage, and built their life anew! They might have even forgotten her!" (338) Sabina seems to have internalised the national anthem that Hindus imposed on the female body and she does not seem to question it. By scapegoating herself, she feels responsible for her family's dishonour, and her only wish is that her family might have forgotten her. Sabita has accepted the fact that her abduction has obliterated her from her community.

When she was rescued by the police, she protested: “'Please, don't take me back', she had begged them earnestly, 'I am quite all right here, and believe me, I don't want to go back home. And even if I do, why should my parents agree to take me back? After all, I have lost my religion and caste now, I have become an untouchable to them"' (343). Sabita's life is marked by loss. She has lost her family, her social position, and her virginity, which is the only merit that validates her as a normative woman within her community. She is presented as a victim that does 
not dare to imagine a different life for herself other than the humiliation and rejection that her community is most surely going to receive her with. However, she has accepted this situation and she avoids lamenting her fate: "Anyway, what would she really gain out of this useless lamentation! This futile regret!" (340)

Sabita has suffered both her abductor's violence and the violence that the State has inflicted on her by means of forcible recovery. She faces the lack of sympathy and coldness of the police: “... the police hadn't listened to her. They had quoted the law, and assured her that even if her parents were reluctant to take her back, there were orphanages that she could go to." (343) She is not allowed to choose. Her only site of resistance is her motherhood, by means of which she feels she can transform hate and animosity into maternal love:

Suddenly, one day she had realized that a tender rapture of motherhood had filled her entire body. There was an exquisite tiredness in her eyes, -it might have been an unwanted and unwelcome child, not born out of love and affection, a mere product of hate and animosity. But still, it was as if she forgave the crime. It was, after all, her own flesh and blood, and she nursed it at her own breast and began to raise him with dreams for his future. (340)

Sabita knows about the illicit circumstances that surround her motherhood, but she feels empowered to fight for her baby. This is the only site of agency that we can find in this character. She is going to do anything to protect her child, who seems the perfect scapegoat for a society that will not welcome him. A good example of this is the fact that she does not reveal his real name to her sister Kabita:

"'He doesn't have a name.' Sabita replied in a dry tone.

In other words, it wasn't possible to tell them the name that he already had.

Kabita's eyes lit up in wonder. 'What, you haven't named him yet?' she said. 'See Ma, what a jolly fellow he is. Tell me, what will you name him? Okay, I have got an idea. You know Didi, the lady next door has named her child Hashi, so we will call this child Khushi, agreed?' (342)

Sabita knows his Muslim name would work as a constant reminder of his otherness; that is, his mixed genealogy. It would have been constantly associated with the other side of the border, which is the case within Sabita's family. For Sabita's family, a Hindu household, her child is Muslim, and, therefore, a sign of past violence, death and dishonour. This is why, Sabita allows her sister to give him a new name and to assign him a new identity to better fit the community. Kabita chooses "Khushi", which means happiness, delight, or joy. The choice is somewhat ironic since the child is condemned to be an outsider and to face the rejection of the whole community.

Sabita's experience as an abducted body is unbearable for her community because her body is a sign that disrupts any patriarchal expectations with regard to Hindu women. Her grief 
has no signifier within the signifying chain of her community. Her grief is unknowable. It is an unarticulated void: "She was at a complete loss for words. What should she say or ask? It was better to remain silent. After all, there was only one thing that she would remember or could be reminded of -the memory of those humiliating days of her past."(340). Her traumatic experience is only meaningful in terms of social humiliation, not in terms of personal suffering. The impossibility of breaking with her silenced grief is vey clear in her encounter with her mother, who does not ask her, does not touch her, does not "see" her. There is a palpable tension between them from the very moment they meet: "She [Sabita] felt somewhat uneasy in her mother's presence." (342). Sabita's presence connects her mother with her own silence, already caused by the loss of Sabita's father and older brother.

In fact, Sabita's presence works in a paradoxical manner as the instigator of a whole community's loss; a community that was confronted with this loss when those abducted women were returned with their marked bodies and their illegitimate children. Their own communities and families would repudiate the women because they would destabilise a whole system of values that had signified female purity as a religious and national requirement for the consolidation of the community.

Her mother epitomises the national and religious narrative and Sabita is aware of this when she arrives home: "Letting out a deep sigh, she looked up once to see her mother. The very next minute her head bent down and her gaze turned to her feet. As if she felt an uneasiness to even raise her face." (340) A mixture of fear of rejection, shame and guilt keeps Sabita and her mother apart. This distance transcends their relationship and responds to an extended collective demand. While Sabita feels touched when she sees her mother's silent tears of grief rolling down her face the moment she sees her for the first time, her mother will rapidly repress her emotional drive responding to her community's expectations. Sabita's mother cannot detach herself from the official rhetoric of the nation. She cannot stop seeing her daughter as a corrupted and defiled body that needs to be washed, cleaned and metaphorically purified. Her presence shames her socially. In fact, they avoid physical contact throughout. Her final confession is a direct result of an escalation in tensions created by her silence, distance and coldness towards her daughter and grandson. In a conversation with her son Boku, Samita's mother confesses her discontent with the child:

'As it is you are unwell, on top of that you have had a bath again in this late evening hour?'

Looking a little embarrassed, her mother said, 'What else could I do, tell me? After all, I have been holding and cuddling the baby the whole day.' 
'So what if you did!' Boku said, in stubborn tone.

'Well,' Sabita heard her mother say 'just because she has raised him in her lap, it does not make him a child of this family, does it?' (344)

After a whole day with her daughter, holding and cuddling her illegitimate grandson, Sabita's mother needs a bath to clean "the dark stain of dishonour" that has fallen on the family. She sees her physical contact with her grandson as polluting. This is the reason why she decides to take a late-night bath, despite the inappropriateness of this act for a woman of her age and in her state of health.

Sabita's family has been partitioned upon the very same lines that India has. This division makes her feel alienated: “... she had to break the wall that stood between her and her family. Otherwise if she continued to maintain a silent distance, then she might remain alien to them, and that would be far more painful and unbearable." (341) It is with the younger generation, her sister Kabita and her brother Boku --who might be less attached to public social dictates-- that she feels strong enough to break the wall that has separated them for a year and a half. From the very beginning, Kabita mediates between Sabita and her mother. She fills the uncomfortable silences that dominate their encounter by trying to forge a grandmother-grandson relationship. Likewise, when Boku comes back from college and sees Sabita, his reaction is warm and loving:

'We had thought that you were not alive.'

'That would have been better, wouldn't it?'

'Rubbish. There's no comfort in dying.' (343)

Boku can't stand his sister's self-destructive comments. He forgets the official narratives that have been written for abducted women and looks at his sister as a human being, as a member of his family, as a loved one. While Sabita's mother wants silence to permeate the trauma -she wants to forget--, her brother and sister want to re-member:

They were waiting so eagerly to talk to their sister, after all, they had so many stories to hear from her. And so many stories to tell also. It had been only a year and a half but it seemed as long as a decade. So many events had taken place, so many changes had occurred. Would they not exchange all that news now? (344)

This younger generation seems to be ready to turn their backs on official collective narratives that stigmatise and shadow abducted women's experiences and Boku is ready to embrace his sister's grief and silence. They are looking forward to filling the gap that Partition has generated in their life and family. They want to re-member the past in order to write their futures. By forcing trauma narratives out of their repressed silent sites, this younger generation seems to be a 
step beyond their parents in healing their wounds.

In this sense, the title of the story becomes deliberately ambiguous. The story seems to confront two types of metaphorical embraces: the older and the younger generation's. While Sabita's mother's holding and cuddling of the child is forced, problematic and contradictory, her brother and sister seem to be ready to embrace their sister's traumatic past as a way to understand their future. ${ }^{5}$

\section{Intergenerational textual dialogues}

These are two stories about borders; borders between families, generations, geographies, national identities, and perhaps most importantly, the border between what is remembered and forgotten, what is told and silenced, what is known and what is "not knowable".

Written from the standpoint of the diaspora and from a second generation post-Partition perspective, Shobha Rao’s “The Lost Ribbon” revisits the Partition of India from an Other space in order to shed some light on the silent unofficial histories of women at a historical moment of conflict when the vulnerability of their bodies was at most risk. "The lost Ribbon" exposes and denounces the violence inflicted on female bodies in Bengal from the perspective of gender and trauma. Ramapada Chaudhuri's "Embrace", written by a first-generation Partition writer, writing from West Bengal, focuses on the difficulties that an abducted woman and her child had to face after their forced repatriation with her family.

On the one hand, Rao's story deals with loss. It narrates explicit episodes of violence during the abduction of a woman who will go through a double displacement. She is abducted, forced to cross the border and leave Bengal, and forced back to the other side of the border, this time in Amritsar, never to reach Bengal again. On the other hand, in Chaudhuri's story, loss is more a context than a central narrative element. "Embrace" does not explicitly deal with the main character's traumatic experience during her abduction but with the aftermath of her repatriation. While Rao's first-person narration establishes an intimate and private relationship with the reader, Chaudhuri's omniscient narrator fails to do so. His story is full of gaps and silences, not only because Sabita forgets and blocks the memory of the traumatic event of her abduction, but also because readers do not have access to her thoughts and feelings. Rao's

\footnotetext{
${ }^{5}$ Note that the original title of the story is "Angapali", which has been translated as "Embrace" in Bashabi Fraser's collection. This is the translation that has been used for the analysis of the story in this chapter. However, Fraser's translation is not the only possible one. Mookerjea-Leonard reads the title differently by taking its literal translation "Body-Guard" or "Protector", to refer both to Sabita as her son's protector as well as to her mother as guarding the purity of her own body and domestic life. (2017: 51)
} 
trauma narrative has been re-written and re-membered by her narrator. This is how we learn about the inevitability of her filicide, which is inscribed within a context of gender violence and female vulnerability that leaves her with no other choice. Rao's narrator allows the reader to understand that her silence is a chosen one.

Although both characters show moments of agency or empowerment in relation to their motherhood, Rao's narrator seems more clearly resistant to the official narratives imposed on her. As a subaltern she won't speak because her actions fulfill neither patriarchal expectations nor female demands. She chooses silence to protect herself from others -Leela's judgement, for instance--, but she has not forgotten. She killed her daughter to protect her from a life of aggression, sorrow and pain.

On the other hand, Sabita's resistance resides in her love for her illicit child, who happens to be a boy. Sabita does not need to leave her boy behind, and can think of a better future for him in Bengal. Her apologetic attitude towards her family signals her internalisation of the discourse of honour, chastity and purity. Furthermore, her feeling of guilt reveals her self-denial or her inability to see herself as a subject. She does not signify the multiple aggressions that she has suffered as a female body and her only worry seems to be acceptance. Sabita will do anything so the community can accept her child as a member of it.

This is why we can conclude that both characters suffer the consequences of genderbased violence and cannot escape the repression of the State/community. However, while Rao's narrator has confronted the official/national narratives imposed on herself as a female body at the expense of becoming a social outcast stagnating in a state institution, Sabita has not articulated her pains and sorrows.

Chaudhuri's more restrained proposal might respond to different variables. His story was published in 1949, two years after Partition, at a time when traumatic events, such as the abduction of women, repatriation and its consequences, were still too vivid and present. He writes from the inside of Partition and he does not have Rao's generational, chronological and spatial distance to deal with certain traumatic silences and gaps. In addition, he writes from the West side of the partition, and he seems to follow a literary tradition that has long had the tendency not to speak explicitly about the violence and brutality of those days. Instead, Rao, writing from the diaspora, revisits an episode in history from an-Other space. Rao's story could be read as a response to Chaudhuri's interpellation to the younger generations to re-member and re-write their older generation's traumatic silences.

The aesthetics of remembering traumatic events/histories requires a crossroads between 
past and present, which implies a constantly fluctuating filter of memory and perspective. This is how history is revealed not as a monolithic field, which sticks to one single Truth-principle but as a productive field where gaps and silences are meaningful. We are still living in a world where patriarchal, economic, social and cultural logic turns the female body into a battlefield to be conquered by patriarchal agendas. Silenced unofficial stories of unrestored female bodies need to be brought to the fore in order to articulate a new space for female subjectivity beyond vulnerability.

\section{WORKS CITED}

ALEXANDER, JEFFREY C (2004). "Toward a Theory of Cultural Trauma." In Cultural Trauma and Collective Identity, edited by Jeffrey C. Alexander, Ron Eyerman, Berhad Giesen, Neil J. Smelser and Piotr Sztompka, 1-30. Berkeley: University of California Press.

BAGCHI, JASODHAR, \& SUBHORANJAN DASGUPTA (eds) (2007). The Trauma and the Triumph: Gender and Partition in Eastern India. Kolkata: Stree.

BANDYOPADHYAY, SEKHAR. (2009). Decolonization in South Asia: Meanings of Freedom in Post-Independence West Bengal. Abingdon: Routledge.

BASU, SAJAL (1982). Politics of Violence: A Case Study of West Bengal. Calcutta: Minerva.

BHALLA, ALOK (2006). Partition Dialogues: Memories of a Lost Home. New Delhi: Oxford University Press.

BROWN, LAURA S. (1995). "Not Outside the Range: Feminist Perspective on Psychic Trauma." In Trauma: Explorations in Memory, edited by Cathy Caruth, 100-112. London: Johns Hopkins University Press.

BUTALIA, URVASHI (2000). The Other Side of Silence: Voices from the Partition of India. 2nd ed. Durham: Duke University Press.

CAMPBELL, JACQUELYNE C. (1999). "Sanctions and Sanctuary: Wife Battering in Cultural Contexts." In To Have and to Hit. Cultural Perspectives on Wife Beating, edited by Dorothy Counts, Judith K. Brown and Jacquelyne C. Campbell, 261-285. Urbana: University of Illinois Press.

CARUTH, CATHY (ed) (1995). Trauma: Explorations in Memory. London: Johns Hopkins University Press.

CHAUDHURI, RAMAPADA (2008). “Embrace.” In Bengal Partition Stories. An Unclosed Chapter, edited by Bashabi Fraser, 337-344. London: Anthem Press.

DIDUR, JILL (2006). Unsettling Partition: Literature, Gender, Memory. Toronto: University of Toronto Press.

FRASER, BASHABI (ed) (2008). Bengal Partition Stories. An Unclosed Chapter. London: Anthem Press. 
GUHA THAKURTA, MEGHNA (2007). "Uprooted and Divided." In The Trauma and the Triumph: Gender and Partition in Eastern India, edited by Jasodhara Bagchi and Subhoranjan Dasgupta, 98-112. Kolkata: Stree.

HARRINGTON, LOUISE (2016). "Crossing Borders in Partition Studies and the Question of Bangladesh Liberation War.” Postcolonial Text 11 (2): 1-16.

HONG, TERRY (2016). "The Recovered \& The Unrestored: Q\&A with Shobha Rao.” Bloom, Dec 7, https://bloom-site.com/2016/12/07/the-recovered-the-unrestored-qa-with-shobha-

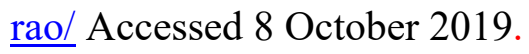

HERMAN, JUDITH L (1997). Trauma and Recovery. New York: Basic Books.

MENON, JISHA (2013). The Performance of Nationalism: India, Pakistan, and the Memory of Partition. Cambridge: Cambridge University Press.

MENON, RITU (ed) (2011). Making a Difference: Memoirs from the Women's Movement in India. New Delhi: Women Unlimited.

MOOKERJEA-LEONARD, DEBALI (2015). "Quarantined: Women and the Partition." In The Indian Partition in Literature and Films: History, Politics, and Aesthetics, edited by Rini Bhattacharya Mehta and Debali Mookerjea-Leonard, 11-35. Abingdon: Routledge.

MOOKERJEA-LEONARD, DEBALI (2017). Literature, Gender, and Trauma of Partition. The Paradox of Independence. Abingdon: Routledge.

PANDEY, GYANENDRA (2004). "Disciplining Difference." In Poscolonial Passages. Contemporary History-writing on India, edited by Saurabh Dube, 159-176. Oxford: Oxford University Press.

RAO, SHOBHA (2017). An Unrestored Woman. London: Fleet.

SAINT, TARUN K (2010). Witnessing Partition: Memory, History, Fiction. Abingdon: Routledge.

TOMSKY, TERRI (2009). "Fifty Years On: Melancholic (Re)collections and Women's Voices from the Partition of India." In Trauma Texts, edited by Gillian Whitlock and Kate Douglas, 57-74. Abingdon: Routledge.

WEBER, RACHEL (2007). "Re(Creating) the Home: Women's Role in the Development of Refugee Colonies in South Calcutta." In The Trauma and the Triumph, edited by Jasodhara Bagchi \& Subhoranjan Dasgupta, 59-79. Kolkatta: Stree,

WHITLOCK, GILLIAN \& KATE DOUGLAS (eds) (2009). Trauma Texts. Abingdon: Routledge.

YOUNG, IRIS MARION (1990). Justice and the Politics of Difference. Princeton: Princeton University Press.

DOLORS ORTEGA ARÉVALO has been a lecturer of Literature in English at the University of Barcelona since the year 2010. She received her PhD degree from the University of Barcelona and she was awarded the European Doctorate Mention after a year as a Visitor Doctorate Researcher at the University of East London. Her research has focused mainly on Contemporary British Fiction and Postcolonial Literatures. 